ROCZNIKI TEOLOGICZNE

Tom LXVII, zeszyt $12-2020$

DOI: https://dx.doi.org/10.18290/rt206712-8

IWAN OSTASZCZUK

\title{
TEOLOGIA POEZJI LITURGICZNEJ W PRZESTRZENI SZTUKI. ANALIZA NA PRZYKŁADZIE OPERY „LEGENDA O NIEWIDZIALNYM GRODZIE KITEZIU I DZIEWICY FIEWRONII"
}

\author{
THEOLOGY OF LITURGICAL POETRY IN THE SPACE OF ART: \\ ANALYSIS ON THE EXAMPLE OF THE OPERA "THE LEGEND OF THE INVISIBLE \\ CITY OF KITEZH AND THE MAIDEN FEVRONIYA"
}

\begin{abstract}
The texts of liturgical poetry are important factors in the formation of works of musical art over the centuries of European music history. This article discusses the theology of liturgical poetry in the space of musical art. The reception of a particular liturgical work in the canvas of musical art creates a corresponding reading of its content in the light of the relevant Christian theological paradigm. Nikolai Rimsky-Korsakov in collaboration with librettist Vladimir Belsky in the opera-legend The Legend of the Invisible City of Kitezh and the Maiden Fevroniya used the textual allusions of the Ortodox church singing Here's the Groom going. The use of church singing from Lent expresses in the finale of the opera the theological ideas of the Second Coming of Jesus Christ, and also presents a picture of the bliss of paradise being in the Kingdom of Heaven.
\end{abstract}

Key words: liturgical poetry; theology; the Second Coming (Parousia); opera The Legend of the Invisible City of Kitezh and the Maiden Fevroniya; the hymn Here's the Groom going.

Wieloaspektowa przestrzeń sztuki jest kształtowana przez wiele czynników - zarówno przez osobiste cechy twórczych osobowości artystów, jak i ogólny kontekst społeczno-historyczny, który prowadzi do rozwiązania pewnych egzystencjalnych pytań ludzkości. Teksty poezji liturgicznej różnych obrządków kościelnych są często wprowadzane do struktury programowych utworów muzycznych, w szczególności opery, symfonii etc. Odbiór

Prof. dr hab. Iwan Ostaszczuk - pracownik Katedry Teologii i Religioznawstwa, Narodowy Uniwersytet Pedagogiczny Imienia M. P. Dragomanowa; adres do korespondencji: ul. Turhenevska 8-14, 01-054 Ukraina, Kijów; e-mail: ostaszczuk@ukr.net. ORCID: 0000-0002-6115-0884. 
określonego dzieła liturgicznego w strukturze dzieła sztuki muzycznej tworzy właściwe odczytanie jego treści w świetle paradygmatu teologicznego określonej tradycji. Chrześcijaństwo prawosławne, poczynając od potężnego źródła duchowości bizantyjskiej, przez stulecia rozwinęło ogromną warstwę muzycznej kultury liturgicznej, która odróżnia się specyficznymi cechami Cerkwi określonego narodu. Majestatyczne teksty liturgiczne były często wykorzystywane w akademickiej sztuce muzycznej. W ten sposób głębokie znaczenia refleksji nad istotą bytu, życiem ludzkim i relacją z Bogiem z systemów religijnych zostają włączone do artystycznych form sztuki muzycznej, przedstawianych współczesnym i kolejnym pokoleniom w celu postrzegania ich w obrazach, zmysłowości, emocjonalności konkretnego dzieła sztuki. Oczywiście ta synteza zależy w dużej mierze od osobowości artysty, w szczególności jego wykształcenia, programu ustanowionego przed napisaniem utworu muzycznego oraz swobodnego lotu twórczej inspiracji, który ujawnia się w percepcji słuchaczy oraz badaczy przez często nieoczekiwane głębiny. Wiadomo, że koncepcja autora często otrzymuje nową interpretację w sposobie widzenia krytyków i teoretyków sztuki. Jest to uwarunkowane perspektywą czasową, jaka dzieli epokę powstania utworu z jej kolejnymi formami interpretacji.

Niniejszy artykuł omawia zagadnienie wprowadzenia znaczeń teologicznych za pomocą tekstów liturgicznych do dzieła muzycznego. Wskazany zabieg zostanie ukazany na przykładzie opery-legendy Nikołaja RimskiegoKorsakowa Legenda o niewidzialnym grodzie Kiteziu i dziewicy Fiewronii ${ }^{1}$, wybitnym dziele muzycznym z początku XX wieku.

Rosyjski kompozytor epoki romantyzmu, członek tzw. Potężnej Gromadki (ros. Могучая кучка; inna nazwa: Rosyjska piątka) ${ }^{2}$ Nikołaj Andriejewicz Rimski-Korsakow (ros. Николай Андреевич Римский-Корсаков; 18441908) nie umieszczał w centrum swoich dzieł muzycznych osobno bohaterów religijnych, a postacie zaczerpnięte z Pisma Świętego lub historii Kościoła nie były przedmiotem jego twórczego zainteresowania. Wiadomo, że wybitny rosyjski kompozytor miał raczej obojętny stosunek do Rosyjskiej

\footnotetext{
${ }^{1} \mathrm{~W}$ języku oryginału (rosyjskim) Сказание о невидимом граде Китеже и деве Февронии.

${ }^{2}$ Chodzi tutaj o pięciu rosyjskich kompozytorów nawiązujących do tradycyjnej rosyjskiej muzyki ludowej, połączonej z nowoczesnymi elementami muzyki Europy Zachodniej. Jako należących do grupy wymienia się Aleksandra Borodina (1833-1887), Milija Bałakiriewa (1837-1910), Cezarego Cuia (1835-1918), Modesta Musorgskiego (1839-1881) oraz Nikołaja Rimskiego-Korsakowa (1844-1908). J. OPYD, Muzykę tworzy naród, czyli „niedzielni kompozytorzy” z Potężnej Gromadki, http://salonliteracki.pl/new/muzyka/717-muzyke-tworzy-narod-czyli-niedzielnikompozytorzy-z-poteznej-gromadki (dostęp: 02.04.2020).
} 
Cerkwi Prawosławnej, prawdopodobnie ze względu na jej nadmierne zaangażowanie w sprawy tego świata, co często pozostawało w sprzeczności z wymiarem biblijnego dekalogu. Jego jednak opera Legenda o niewidzialnym grodzie Kiteziu i dziewicy Fiewronii (1903-1904), uważana za oryginalny duchowy testament kompozytora, ma wyraźny podtekst liturgiczny, a nawet określana jest jako „opera liturgiczna”. To dzieło Rimskiego-Korsakowa jest poświęcone m.in. tematyce chrześcijańskiej inspirowanej przesłaniem mistycznym, jak również opartej na legendach chrześcijańskich oraz przesłaniu zaczerpniętym $\mathrm{z}$ apokryfów. Takie poszukiwanie tematyki było spowodowane dwoma głównymi czynnikami, a mianowicie miejscem urodzenia oraz zamieszkania samego artysty. Pochodził on $\mathrm{z}$ małego rosyjskiego miasteczka Tichwin w guberni Nowogrodzkiej. Szlachecki dom rodziny Rimskich-Korsakowych znajdował się na brzegu rzeki Tichwinka naprzeciwko znanego w tym regionie klasztoru Zaśnięcia Matki Bożej. To znane i popularne centrum pielgrzymkowe głęboko zapadło w pamięć artysty. W umyśle małego Nikołaja głęboko utrwaliły się obrazy związane z kultem oraz pobożnością ludową, które dosłownie widział z okien swojego domu. Wspomnienia z dzieciństwa są więc dla Rimskiego-Korsakowa kluczowym kryterium, dzięki któremu mógł rozwinąć się proces adaptacji rosyjskiej muzyki ludowej poprzez twórcze wykorzystanie jej motywów w operach, utworach symfonicznych czy wokalnych. W przypadku twórczości przywołanego artysty późniejszy wysoki poziom edukacji i kultury zbiegł się z głębokim doświadczeniem muzyki Cerkwi prawosławnej, którą Rimski-Korsakow poznawał już od najmłodszych lat swego życia.

Analiza twórczości Nikołaja Rimskiego-Korsakowa pozwala stwierdzić, że w jego operach, w przeciwieństwie chociażby do dzieł Piotra Iljicza Czajkowskiego, nie ma odzwierciedlenia świata ludzkich uczuć, ludzkiego serca. Znajduje się w nich natomiast jedynie odwołanie do fantazji, narracji starożytnych słowiańskich legend ukrytych pod zasłoną mitów. W ten sposób krytycy pozwolili sobie na stwierdzenie, że twórczość Rimskiego-Korsakowa to zwierciadło, które odbija światopogląd zaczerpnięty z legend o dawnych bohaterach, bardzo odległych od problematyki człowieka końca XIX i początku XX wieku. Należy jednak zauważyć, że wszędzie przez pryzmat mityczny i legendarny, zanurzony $\mathrm{w}$ archetypowych warstwach obrazów, wybitny kompozytor reprezentowal wysokie rejestry dramatu ludzkich doświadczeń i stanów egzystencjalnych. Błędem jest zatem ocena, że jego sztuka operowa (podobnie jak inne gatunki muzyczne) nie przynosi współczesnemu człowiekowi owocnego materiału do refleksji nad życiem i najwyższymi uczuciami. 
Analizę opery Legenda o niewidzialnym grodzie Kiteziu i dziewicy Fiewronii należy rozpocząć od charakterystyki jej libretta. W przypadku analizowanej opery autorem libretta jest poeta Władimir Bielski (1866-1946). Uważa się go za eksperta w zakresie dzieł Rimskiego-Korsakowa, któremu sam kompozytor ufał i pozostawiał pewną dowolność w zakresie fabuły i prezentacji obrazów, które są tłem powstającego dzieła muzycznego. W sztuce operowej twórczy dialog librecisty i kompozytora jest bardzo ważny, ponieważ tekst włożony w usta aktorów koncentruje się w szczególności na kwestiach, które chce wyrazić ideowy poziom dzieła. W przypadku Nikołaja Rimskiego-Korsakowa i Władimira Bielskiego spotykamy się z bardzo owocnym oraz twórczym tandemem. Jego wynik stał się znaczący, a jednocześnie oryginalny w swoich muzycznych cechach. Konsekwencją jest to, że mimo upływającego czasu oraz zmieniających się możliwości technicznych opisywana opera nie została jeszcze w pełni zaprezentowana w zakresie swej scenicznej wymowy.

Wydaje się, że cytowanie libretta $\mathrm{w}$ badaniach naukowych jest ważne, ponieważ na scenie jego tekst nie zawsze może być wyraźnie usłyszany i zrozumiany. Wiąże się to $\mathrm{z}$ tym, że synteza muzyki i opowieści na scenie ma charakter dynamiczny. Akt IV, scena 1, w której librecista rysuje prawdziwie rajskie obrazy, wśród których przebywa dziewica Fiewronia, po licznych próbach, udrękach i cierpieniach: „Fiewronia została sama. Leży na trawie. Drzewa stopniowo pokryte są jasnymi szmaragdowymi zieleniami o osobliwym wyglądzie. Fiewronia pogrąża się w błogim stanie: minęły zmęczenie i ból. Śpiewa kołysankę dla siebie samej: «Бай, бай, спи, усни, спи, сердечко, отдохни» ${ }^{3}$. Woskowe świece zapalają się wszędzie na gałęziach drzew; ogromne bajeczne kwiaty rosną z drzew i z ziemi [...] Głosy rajskich ptaków będą prorokować jej spokój i szczęście"4. Ten idylliczny romantyczno-mistyczny obraz z libretta opery Rimskiego-Korsakowa przypomina scenę wejścia lirycznego bohatera w Boskiej komedii Dantego do wiecznego szczęścia raju. Dokonuje się to po jego podróży przez ciemne lochy kręgów piekła i przez napełnione świetlaną nadzieją tarasy czyśćca.

Fiewronia (sopran) w arii zachwycona jest rajskimi obrazami i bajecznymi widokami, które nagle pojawiły się w ciemnym lesie, gdzie ona znajduje się w całkowitej samotności:

\footnotetext{
${ }^{3}$ Cytaty z libretta opery tu i dalej zostały podane w języku oryginału (rosyjskim).

${ }^{4}$ А. МАйКАРП, Опера Римского-Корсакова «Сказание о невидимом граде Китеже и деве Февронии», https://www.belcanto.ru/kitezh.html (dostęp: 19.03.2020).
} 
Посмотрю я, что здесь цветиков,

и какие все чудесные!

Все вокруг меня сомкнулися

и головками киваючи,

мне поклоны бьют низехонько,

госпожу свою приветствуя.

Ах, вы ласковые цветики,

райский крин неувядаемый!

Таковая превелика честь

Не пристала сиротинушке.

(оглядывается)

Али вновь весна красна пришла?

Все болота разлелеялись,

все деревья разукрасились,

что боярышни к злату венцу;

(запевают весенние птицы)

разыгрались пташки вольныя,

темны заросли покинули.

$$
(\text { akt IV, scena } 1)^{5}
$$

W tym momencie, gdy główna bohaterka jest gotowa umrzeć $\mathrm{z}$ radością $\mathrm{i}$ pokojem po licznych próbach życia, po tak pięknym i przyciągającym obrazie rajskiego bytu, duch księcia Wsiewołoda idzie do niej z głębi lasu ścieżką pokrytą kwiatami i oświetloną złotym promieniem. Obraz można odnieść do sceny Przemienienia Chrystusa tak popularnego w malarstwie europejskim. Duch przemawia następnie do Fiewronii:

Веселись, моя невеста, веселись!

По тебя жених пришел

$$
(\text { akt IV, scena } 1)^{6}
$$

Za sceną natomiast śpiewa głos fantastycznego ptaka Sirina:

Се жених пришел, что же медлиши?

Красный пир готов, поспешай к нему

$$
(\text { akt IV, scena } 1)^{7}
$$

\footnotetext{
${ }^{5}$ В. И. БЕльский, Сказание о невидимом граде Китеже и деве Февронии, http://az. lib.ru/ b/belxskij_w_i/text_1903_skazanie_o_kitezhe.shtml (dostęp: 19.03.2020).

${ }^{6}$ Tamże.

${ }^{7}$ Tamże.
} 
Następnie Fiewronia rozpoznaje księcia, którego nie spodziewała się zobaczyć na tym świecie, i razem kontynuują śpiew:

Даст Господь нам ныне радости, а ее ж не знали мы, явит оку свет невиданный, тихий, незакатный свет

$$
\text { (akt IV, scena } 1)^{8}
$$

Para zakochanych udaje się następnie do cudownie przemienionego grodu Kiteziu, o którym zachwyceni mieszkańcy w chórze wykonują końcowy hymn opery:

Здесь ни плача, ни болезни, сладость, сладость бесконечна,

Радость вечна...

$$
\text { (akt IV, scena } 2)^{9} \text {. }
$$

Analizując przywołane libretto, Władimir Bielski napisał: „W całym utworze nie będzie ani jednego drobiazgu, który nie byłby inspirowany cechą jakiejkolwiek legendy, wiersza, zaklinania lub innych owoców rosyjskiej sztuki ludowej" $"$. Inspiracje zatem zawarte w utworze w pełni czerpią z instrumentarium ludowego odwołując się także do toposów zaczerpniętych z Objawienia.

W staroruskiej intonacyjności opery wyróżnia się jej własną intonację i temat wyraźnie teologiczny związany z ewangelicznym śpiewem cerkiewnym Oto Oblubieniec nadchodzi ${ }^{11}$. Marina Rachmanowa pisze o stylistyce opery: „Jedyny cytat takiego rodzaju w Kiteziu - śpiew Oto Oblubieniec nadchodzi obecny w scenie pojawienia się zabitego Księcia - należy nie do znamennego, ale do kijowskiego (czyli późniejszego) śpiewu i jest wzięty przez kompozytora jako łatwo rozpoznawalny dla słuchacza motyw, który ma bezpośrednie odniesienie. Mianowicie zarówno w czasach RimskiegoKorsakowa, jak i współcześnie śpiew ten wybrzmiewa w świątyniach w liturgii Wielkiego Tygodnia, oraz w operze - przed Chożdienijem $w$ gród niewidzialny" ${ }^{\prime 2}$. Tradycja kijowskiego śpiewu monodii (forma śpiewu jednogłosowego) pochodzi z etnicznych ziem ukraińskich i białoruskich, skąd w drugiej

\footnotetext{
${ }^{8}$ Tamże.

${ }^{9}$ Tamże.

${ }^{10}$ Tamże.

${ }^{11}$ Cerkiewnosłowiański: Се гряде Жених.

12 М. РАхманова, Опера Римского-Корсакова «Сказание о невидимом граде Китеже и деве Февронии», https://www.belcanto.ru/kitezh.html (dostęp: 19.03.2020).
} 
połowie XVII wieku trafiła do Moskwy. Przez to stała się powszechnie obecna w śpiewach liturgicznych Cerkwi moskiewskiej ${ }^{13}$. Na ziemiach moskiewskich do tego dominował tzw. śpiew znamenny, który pojawił się na terenach Rusi Kijowskiej wraz z przyjęciem chrześcijaństwa z Bizancjum.

Należy zauważyć, że teologia prawosławnego hymnu Oto Oblubieniec nadchodzi, którego inspiracje pojawią się w przywołanym libretcie, jest wynikiem twórczego poszukiwania kompozytora i subtelnego oczekiwania w duszy na słowo. Chodzi o cichy głos, który wybrzmi w konkretnej scenie muzycznej Kitezia. Przywołany hymn wielkopostny ma ważne znaczenie w oczekiwaniu drugiego przyjścia Jezusa Chrystusa, tzn. Paruzji. Według prawosławnej teologii „najprawdopodobniej Paruzja odbędzie się w nocy. Wskazuje na to przypowieść Zbawiciela o 10 pannach, w której Jego przyjście jest przyrównane do oblubieńca przychodzącego do swoich narzeczonych: «Lecz o północy rozległo się wołanie: Pan młody idzie, wyjdźcie mu na spotkanie!» (Mt 25,6). W innej przypowieści dla przedstawienia Paruzji używany jest obraz złodzieja, który zawsze pojawia się nagle i przeważnie w nocy (Mt 24,43). Paweł Apostoł wskazuje, że «dzień Pański przyjdzie tak, jak złodziej w nocy» (1 Tes 5,2). Pośrednim świadectwem na korzyść „nocnej” Paruzji może być Pierwsze przyjście Chrystusa, to znaczy jego narodzenie, które miało miejsce w nocy. Korzystając $z$ tych obrazów i analogii, tradycja liturgiczna zaczęła łączyć drugie przyjście Syna Bożego właśnie z nocą. («Се Жених грядет в полунощи, и блажен раб, его же обрящет бдяща...» - tropar Wielkiego Poniedziałku, Wtorku oraz Wielkiej Środy)" ${ }^{\prime 4}$. Śpiewanie i słuchanie tego hymnu w Wielkim Tygodniu powinno wyraźnie przypominać prawosławnym chrześcijanom, że przyjście Chrystusa jest bliskie, a czas Wielkiego Postu, przeznaczony każdego roku na duchowe nawrócenie, zbliża się do końca. Być może dla wielu, to ostatni okres przygotowań do Wielkanocy w ich życiu ziemskim. Być może dla kogoś, wkrótce trzeba koniecznym okaże się by stanąc przed Sędzią nieba i ziemi. Dlatego też, jak oblubienica musi oczekiwać swego Oblubieńca, każdy chrześcijanin musi być gotowy na spotkanie ze swoim Panem w wieczności.

Programowe dzieło Rimskiego-Korsakowa, jakim jest analizowana opera, można uznać za przejaw aktywnej współpracy samego kompozytora z librecistą W. Bielskim. Sam librecista dokładnie orientował się we wcześniejszej

\footnotetext{
${ }^{13}$ Е.Ю. Шевчук, С.И. Никитин, Киевский расnев, http://www.pravenc.ru/text/1684569.html (dostęp: 19.03.2020).

${ }^{14}$ М.С. Иванов, Второе Пришествие, http://www.pravenc.ru/text/155586.html (dostęp: 19.03.2020).
} 
twórczości kompozytora: „Rimski-Korsakow w osobie Bielskiego miał wyjątkowo dobrze wykształconego i utalentowanego współpracownika. Bez przesady możemy nazwać libretto Kitezia najlepszym w rosyjskiej muzyce operowej” ${ }^{\prime 15}$. W przedmowie do libretta opery Bielski zauważył: „Podsumowując być może warto przypomnieć, że plan i tekst obecnej opery, której myśl przyszła do N.A. Rimskiego-Korsakowa przed napisaniem Sattana (1899), na wszystkich etapach podlegały wspólnemu z kompozytorem omówieniu. Dlatego kompozytor we wszystkich szczegółach przemyślał i odczuł wraz z autorem tekstu nie tylko główną ideę, ale także wszystkie szczegóły fabuły, a zatem nie może być w tekście żadnej intencji, która nie byłaby zaakceptowana przez kompozytora" ${ }^{" 16}$. Tak więc analizowane dzieło jest przejawem ścisłej współpracy kompozytora i librecisty. Analizując zacytowaną wypowiedź, można podsumować, że żaden $\mathrm{z}$ tekstowych ani muzycznych aspektów opery nie był w żaden sposób przypadkowy. Kompozytor, ufając młodemu libreciście, w pełni aprobował aplikowane w dziele odniesienia cerkiewno-liturgiczne.

Opera pt. Legenda o niewidzialnym grodzie Kiteziu i dziewicy Fiewronii jako dzieło może być rozpatrywana również w perspektywie wcześniejszego dorobku N. Rimskiego-Korsakowa. Zamieszczone w utworze muzyczne aluzje i reminiscencje z innych dzieł muzyki rosyjskiej, w tym cerkiewnej, pozwalałyby tworzyć klucz podobieństw. W perspektywie tego stwierdzenia badaczka twórczości kompozytora Marina Rachmanowa zauważa: „Niemniej jednak libretto Kiteziu nie jest kompilacją, lecz oryginalnym dziełem, a główne obrazy Legendy - Fiewronia i Griszka Kutierma oczywiście nie mogły być znalezione w źródłach staroruskich. Po raz pierwszy od Śnieżki kompozytor otrzymał tekst o tak wysokiej jakości artystycznej oraz, co równie ważne, fabułę i tekst tak głęboko związane nie tylko $\mathrm{z}$ jego bezpośrednimi intencjami artystycznymi, ale także z podstawowymi zasadami jego osobowości. W Śnieżce był to szczęśliwy zbieg okoliczności, Kiteż został natychmiast wykonany na wzór Rimskiego-Korsakowa" ${ }^{17}$.

W liście jednego z czcicieli twórczości Rimskiego-Korsakowa zwrócono uwagę na oczekiwania współczesnych kompozytora dotyczące dość wyraźnie religijnej treści analizowanej opery, co było pewnym novum $\mathrm{w}$ jego utworach: „W twórczości Rimskiego-Korsakowa zawsze istniał patos reli-

\footnotetext{
${ }^{15}$ М. РАхманова, Опера Римского-Корсакова «Сказание о невидимом граде Китеже и деве Февронии».

${ }^{16}$ В.И. БЕльский, Сказание о невидимом граде Китеже и деве Февронии.

${ }^{17}$ М. РАхманова, Опера Римского-Корсакова "Сказание о невидимом граде Китеже и деве Февронии».
} 
gijny - w formie entuzjastycznego stosunku do świata jako całości, w formie uwielbienia wiecznej kobiecości (Panienka, Śnieżka, Wołchowa, Łabędź, Marfa, a zwłaszcza Młada), ale on używał elementów chrześcijańskich tylko przypadkowo. [...] Mam nadzieję, że muzyka religijna Rimskiego-Korsakowa będzie potężna, wesoła, a nie pokutna, przygniatająca - jednym słowem, à la Wasniecow, a nie à la Niestierow"18. Cytowany fragment listu pokazuje ogólne odrzucenie oficjalnej religijności prawosławnej w środowisku ówczesnej rosyjskiej inteligencji, jak również takiej twórczości. Taka sytuacja naturalnie wynikała $\mathrm{z}$ praktyki drastycznej cenzury, ścisłego tandemu Rosyjskiej Cerkwi Prawosławnej z carskim samodzierżawiem (monarchiczną autokracją), w tym kontroli nad przejęciem sakramentów oraz przejawem wolności myśli, które szczególnie obfitowało w rosyjskiej kulturze i sztuce na przełomie XIX i XX wieku.

W zarysowanej powyżej perspektywie na uwagę zasługuje fragment biografii kompozytora, z której wiadomo, że miał on raczej chłodne i odległe podejście do synodalnego, oficjalnego rosyjskiego prawosławia. Jego jednak percepcja religii państwowej i osobiste poszukiwanie dialogu z Bogiem powinny być tutaj oddzielone. Można to wyraźnie stwierdzić na przykładzie analizy przywoływanej w treści opracowania opery. Wydaje się niemożliwe, ażeby kompozytor, pod koniec życia podsumowując niejako własną twórczość, przedstawił w analizowanym utworze jedynie formalną stylizację średniowiecznej rosyjskiej religijności. Bardziej zasadne jest stwierdzić, że dojrzały kompozytor (analizowana opera powstała na rok przed śmiercią artysty) stworzył dzieło, w którym wątki mistyczne i religijne były świadomym i przemyślanym ruchem. W tle warto przytoczyć myśl J. Abrahama, angielskiego badacza twórczości Nikołaja Rimskiego-Korsakowa: „Kiteź obiektywnie nie może być interpretowany jedynie z zewnętrznej charakterystyki wiary, do której artysta był obojętny lub wobec której wykazywał czysto estetyczne zainteresowanie... Kiteź jest tak wyraźnym czymś innym, że nie sposób nie zastanawiać się nad jego znaczeniem w życiu duchowym kompozytora. Czy idea Kitezia była jedynie triumfem instynktu nad rozumem? Czy w późniejszych latach Rimski-Korsakow w jakimś sensie zgodził się z prawosławiem? Czy może on i Bielski sądzili, że znaleźli esencję chrześcijaństwa w duszy natury? Nie ma odpowiedzi na te pytania"19. Warto zauważyć, że analiza życia artysty nie zawiera dowodów dotyczących poszukiwania przez niego drogi do Boga. W jego twórczości pojawia się natomiast

\footnotetext{
18 Tamże.

${ }^{19}$ Tamże.
} 
podtekstowo coś, czego nie może wyraźnie zweryfikować lub nie do końca określić. Chodzi mianowicie o jego kierunek wewnętrznej drogi myśli oraz intuicji, której przejawem jest przecież jego twórczość. Sztuka muzyczna pozwalała mu, jako narzędzie, wyrażać pewne stany emocjonalne, prezentować przeżywane intuicje duchowe oraz wewnętrzne poszukiwania.

Całość prezentowanej dyskusji nad budową analizowanej opery może uzyskać nową interpretację dzięki religijnemu, cerkiewno-muzycznemu wymiarowi analizowanego dzieła. Budowę opery można bowiem prześledzić na poziomie gatunku i tematyki: „B.W. Asafiew porównał dramaturgię pierwszego aktu do Wieczerni [nieszporów - dopisek I.O.], w której uwielbienie Stwórcy i stworzenia osiąga kulminację w wielkiej chwale Fiewronii, oraz pierwszą scenę trzeciego aktu sceny w Wielkim Kiteziu - ze śpiewem akatystu [pochwalny hymn liturgiczny na cześć Jezusa Chrystusa, Bogarodzicy lub świętych w Cerkwi prawosławnej - dopisek I.O.]. Rzeczywiście, prawie cała ta scena, na której koncentruje się epicka linia opery, opiera się na formach rytualnych: najpierw na ludowo-epickich strukturach pytań i odpowiedzi (Pojarok i kitezianie), a następnie na antyfonach chóru i solisty (trzykrotne prowadzenie znamennego tematu modlitwy do Niebiańskiej Królowej oraz odpowiedzi wyrażone ustami Otroka), dalej, po odejściu drużyny, kontynuacja antyfonalnego śpiewu w scenie zanurzenia grodu"20. Takie gatunkowo-tematyczne cechy świadczą o głębokim obeznaniu kompozytora $\mathrm{z}$ tradycjami cerkiewnej muzyki prawosławnej.

Rosyjski krytyk muzyczny Eugeniusz Petrowski wprowadził termin „opera liturgiczna" (pierwotnie w odniesieniu do innej opery Rimskiego-Korsakowa Sadko), to znaczy: „opera wyemancypowana z realistycznych wymagań teatru dramatycznego [...] opera, która odważyła się na piękną umowność, na harmonijne i dobre uformowanie (jak tragedia Greków) wydarzeń przedstawionych w całości, na symbolizm, być może zbliżony do symboliki nabożeństw cerkiewnych, chociaż stosowany do innej treści" ${ }^{21}$. Należy zauważyć, że krytyk muzyczny przy definiowaniu takiego gatunku nie oznaczał podobieństwa treści, problemów, tematów, obrazów ze sztuką liturgiczną Cerkwi prawosławnej, ale pisał o oryginalnej dramaturgii muzycznej, charakterystycznej dla chrześcijaństwa bizantyjskiego oraz zachodnich obrządków kościelnych.

Struktura prezentowanej opery mimo obecnych w niej wątków i odniesień liturgicznych nie może zostać uchwycona w perspektywie pewnego schematyzmu (możliwego do powielenia). W kościelnej dramaturgii liturgii i para-

\footnotetext{
${ }^{20}$ Tamże.

${ }^{21}$ М. РАхманова, Опера Римского-Корсакова «Сказание о невидимом граде Китеже и деве Февронии».
} 
liturgii występuje wyraźny element cyklicznie powtarzającego się misterium, czego sam Rimski-Korsakow pragnął uniknąć. W liście do E. Petrowskiego kompozytor pisał: „[...] Odchylenia [...] w stronę realistyczną, jak sądzę, powinny zawsze istnieć. One napełnią życiem i różnorodnością formę liturgiczną, bez której forma ta może łatwo wpaść w jednolitość i kostnienie liturgii cerkiewnej”22. Właśnie takim dynamicznym realizmem kompozytor starał się odróżnić własną operę od misterium sakramentów i standaryzacji kościelnej dramaturgii muzycznej.

Podsumowując, warto jeszcze zwrócić uwagę na ciekawy aspekt, jaki został podkreślony $\mathrm{w}$ tłumaczeniu tytułu opery na język niemiecki. Kompozytor, rozmawiając $\mathrm{z}$ thumaczem $\mathrm{F}$. Grusem, zwraca uwagę na dokonaną zmianę w przekładzie, gdzie tłumaczenie: Weltverklarte Stadt (,przemieniony gród") nie oddaje tego, co można uzyskać w wyrażeniu: Unsichtbare Stadt („niewidzialny gród”). Kompozytor pisał: „Fabuła mojej opery ma duchową konotację i zapożyczona jest $\mathrm{z}$ opowieści raskolników ${ }^{23}[\ldots]$ Znaczenie jej [niemieckiej nazwy] wydawało się mniej jeszcze odpowiednie do treści opery, rosyjskie słowo «niewidzialny» (невидимый) [...] nie ma duchowego odcienia, można to podkreślić $\mathrm{w}$ tytule, dzięki temu jednak utraci sens i nie okaże się niczym udramatyzowanym, a przez to dostosowanym do wymiaru duchowego, pomimo niektórych scen o charakterze świeckim" ${ }^{24}$. W teologii chrześcijańskiej znaczenie pojęcia „przemienienie” ma głębokie znaczenie duchowe. Podobnie jak Apostołowie weszli na górę Przemienienia Jezusa Chrystusa, tak też wszyscy bohaterowie opery Rimskiego-Korsakowa zmierzają w kierunku osiągnięcia niewidzialnego, ,przemienionego” grodu - Kitezia. Jest to podporządkowane całej dramaturgii i muzycznej stylistyce opery.

Opera Legenda o niewidzialnym grodzie Kiteziu $i$ dziewicy Fiewronii Mikołaja Rimskiego-Korsakowa dzięki włączeniu do struktury tekstu libretta łączy muzyczną przestrzeń aluzji prawosławnych pieśni liturgicznych, wyraża jednocześnie znaczenie tematu i obrazów chrześcijańskiej teologii. Licentia poetica Nikołaja Rimskiego-Korsakowa i Władimira Bielskiego przedstawia oryginalną twórczą prezentację ważnej chrześcijańskiej prawdy o powtórnym przyjściu Zbawiciela. Przykład analizy fragmentu opery (akt IV scena 1), na

\footnotetext{
${ }^{22}$ Tamże

${ }^{23}$ Raskolniki, staroobrzędowcy, starowierzy, starowiercy - wyznanie w Rosyjskiej Cerkwi Prawosławnej powstałe wskutek rozłamu (ros. раскол) ро reformie liturgicznej patriarchy Nikona i cara Aleksego I Michajłowicza z lat 1650-1660, upodabniającej księgi liturgiczne i obrzędy cerkiewne do greckich.

${ }^{24}$ М. РАхманова, Опера Римского-Корсакова «Сказание о невидимом граде Китеже и деве Февронии».
} 
który silny wpływ ma prawosławny śpiew (tropar) Oto Oblubieniec nadchodzi, dowodzi, że w ten sposób ukazane jest znaczenie chrześcijańskiego przesłania o drugim, chwalebnym przyjściu Jezusa Chrystusa - Paruzji. Finał opery (arie Fiewronii, księcia, śpiew chóru) wyrażają idylliczny obraz raju, który zaistnieje po końcu świata w ,przemienionym” grodzie Kiteziu - który może się stać oryginalną reminiscencją eschatologicznej Nowej Jerozolimy.

\section{BIBLIOGRAFIA}

БЕльский В.И., Сказание о невидимом граде Китеже и деве Февронии [BEL'SKIY V.I., Skazaniye o nevidimom grade Kitezhe i deve Fevronii], http://az.lib.ru/b/ belxskij_w_i/ text_1903_skazanie_o_kitezhe.shtml (dostęp: 19.03.2020).

Иванов М.С., Второе Пришествие [Ivanov M.S., Vtoroye Prishestviye], http://www.pravenc.ru/ text/155586.html (dostęp: 19.03. 2020).

МАЙКАПАР А., ОПера Римского-Корсакова «Сказание о невидимом граде Китеже и деве Февронии» [MAYKAPAR A., Opera Rimskogo-Korsakova «Skazaniye o nevidimom grade Kitezhe i deve Fevronii»], https://www.belcanto.ru/kitezh.html (dostęp: 19.03.2020).

OpYD J., Muzykę tworzy naród, czyli ,niedzielni kompozytorzy” z Potężnej Gromadki, http:// salonliteracki.pl/new/muzyka/717-muzyke-tworzy-narod-czyli-niedzielni-kompozytorzy-zpoteznej-gromadki (dostęp: 02.04.2020).

РАХманова М., Опера Римского-Корсакова «Сказание о невидимом граде Китеже и деве Февронии» [RAKhmanova M., Opera Rimskogo-Korsakova «Skazaniye o nevidimom grade Kitezhe i deve Fevronii»], https://www.belcanto.ru/kitezh.html (dostęp: 19.03. 2020).

Шевчук Е.Ю., Никитин С. И., Киевский распев [SHEvснUк Ye.YU., NiкiтıN S. I., Kiyevskiy raspev], http://www.pravenc.ru/text/1684569.html (dostęp: 19.03.2020).

\section{TEOLOGIA POEZJI LITURGICZNEJ W PRZESTRZENI SZTUKI. ANALIZA NA PRZYKŁADZIE OPERY „LEGENDA O NIEWIDZIALNYM GRODZIE KITEZIU I DZIEWICY FIEWRONII”}

Streszczenie

Teksty poezji liturgicznej są ważnymi czynnikami w tworzeniu dzieł sztuki muzycznej na przestrzeni wieków europejskiej historii muzyki. Niniejszy artykuł omawia zagadnienie teologii poezji liturgicznej w przestrzeni sztuki. Recepcja określonego dzieła liturgicznego w sztuce muzycznej powoduje odpowiednie odczytanie jego treści w świetle konkretnego chrześcijańskiego paradygmatu teologicznego. Nikołaj Andriejewicz Rimski-Korsakow we współpracy z librecistą Władimirem Belskim w operze-legendzie Legenda o niewidzialnym grodzie Kiteziu i dziewicy Fiewronii wykorzystał aluzje tekstowe cerkiewnego śpiewu Oto Oblubieniec nadchodzi. Zapożyczenie śpiewu cerkiewnego z okresu Wielkiego Postu wyraża w finale opery teologiczne idee Drugiego Przyjścia Jezusa Chrystusa (paruzji), a także przedstawia obraz błogości raju życia wiecznego w Królestwie Niebieskim.

Słowa kluczowe: poezja liturgiczna; teologia; Drugie Przyjście Jezusa Chrystusa (paruzja); opera pt. Legenda o niewidzialnym grodzie Kiteziu i dziewicy Fiewronii; hymn Oto Oblubieniec nadchodzi. 